\title{
Reverse Logistics Activities in Turkey
}

\author{
Türkiye'de Ters Lojistik Faaliyetleri \\ Elif GiLANLI ${ }^{1}$, Nevin ALTUĞ², Adil OĞUZHAN ${ }^{3}$
}

\begin{abstract}
Reverse logistics is becoming more important in recent years regarding the standards related with environment that were determined by EU and developed countries and increasing of customer satisfaction. In this study, the reverse logistics concept, which is a brand new understanding in Turkey, was examined. A survey study was made on facilities activating in Thracian region and it was examined whether they apply reverse logistics or not, the reasons why they apply reverse logistics and the problems faced during the application for reverse logistics.
\end{abstract}

Keywords: Green supply chains, reverse logistics, recycle, reproduction

\section{INTRODUCTION}

Since 1960's till 2000's, companies used several management systems. The basis of these systems are increasing quality, maximizing profitability and minimizing costs. Supply chain management is a method that submits the correct product to the customer at correct time, correct place and correct price with the lowest possible cost for the whole supply chain and also integrates material, information and cash flow (Şen, 2006). Increasing competition in the globalizing world, increasing expectations of the consumers and the decreasing lifetime of the products puts the producers in a difficult position. Today, the consumers become more conscious regarding environmental issues day by day and heading for less environmentally damaging products and companies.

\section{THEORETICAL BACKGROUND}

\subsection{Definition of Reverse Logistics Concept}

The social responsibility and ethics concepts, whose importance increases day by day which may persuade the chains of the facilities to different methods. Green supply chain is one of the most important examples of this situation (http://www.hilalyildirirkeser.com, 30.06.2011). The green applications in supply chain increase the job satisfaction and life quality of the community

\section{ÖZET}

Avrupa Birliği ve gelişmiş ülkelerin ortaya koyduğu çevre ile ilgili standartlar ve müşteri memnuniyetinin arttııılmasında ters lojistik konusu son yıllarda çok daha fazla gündeme gelmektedir. Bu çalışmada, Türkiye'de henüz çok yeni bir anlayış olan ters lojistik kavramı üzerinde durulmuştur. Trakya Bölgesi'nde faaliyet gösteren işletmeler üzerinde bir anket çalışması yapılarak işletmelerin ters lojistik uygulayıp uygulamadıkları, işletmelerin ters lojistik uygulama nedenleri ve ters lojistik uygulama aşamasında yaşanılan sıkıntılar incelenmiştir.

Anahtar Kelimeler: Yeşil tedarik zinciri, ters lojistik, geri dönüşüm, yeniden üretim

and create a value to the company. Green supply chain management can be defined as a whole of green purchasing, green production / material management, green distribution / marketing and reverse logistics (Büyüközkan and Vardaloğlu, 2008:66-73). The green companies generally have 3 purposes. These are; decreasing of consumption, reusing, recycling (Erdal vd., 2008:499).

Reverse logistics is the whole of all processes regarding the movement of products with the purpose of re-obtaining value or properly disposal (Rogers ve Tibben-Lembke, 1998).

Reverse logistics which is also an important concept in means of customer satisfaction, starts when customer sends the broken good he owns back for fixing or changing and it ends when fixed or changed product is sent back to the customer (Çancı and Erdal, 2009:48). Sometimes the packaging of the products may be sent back for re-use. Some materials (glass, metal, plastic) and hazardous chemicals are also taken back for safe destruction (www.muhasebedergisi.com, 29.06.2011). The backward flow of the materials which are not needed by the user anymore or which are expired to the related facilities for recycling is called reverse logistics (Yüksel, 2002:261-279).

Reverse logistics consists of all activities such as

\footnotetext{
1 Lecturer, Trakya University, Havsa Vocational School, Department of Management and Organization, elifgilanli@yahoo.com.tr

${ }^{2}$ Assist. Prof., Trakya University, Faculty of Economics and Administrative Sciences, Department of Business Administration, naltug2002@yahoo.com

${ }^{2}$ Assist. Prof., Trakya University, Faculty of Economics and Administrative Sciences, Department of Econometrics, adog@trakya.edu.tr
} 
management, process, reduction and disposal of hazardous and non-hazardous wastes, packaging and product usage. (Dyckhoff vd., 2004:164). The importance and effect of reverse logistics vary from sector to sector and the place of the company in the distribution channel. The reverse logistics activity importance is high in sectors where product value, variety and recycling is high. Automotive part industry is a good example for that. The reproduced automotive part market is considered to be 36 billion USD in USA. 95\% of all starters and alternators are reproduced and reused. (Şengül, 2009). Generally it is considered that $20 \%$ of all sold products are recycled and companies use $5 \%$ of their total logistics costs for reverse logistics. (Nakıboğlu, 2007:181-196).

When recycle logistics is evaluated in means of costs, it corresponds to the $10 \%$ of Turkish economy. At the same time, it eases the new raw material supply of the companies and raw material costs drastically decreases as raw material is not reproduced (Erdal vd., 2008:499). The reverse logistics cost in USA is $4 \%$ of the total logistics costs (Stock, 2001:5-11). Reverse logistics reveals the undesired costs. Therefore the total costs of reverse logistics should be managed in order to control the costs of the products delivered to the customers. (http://www.persemberotasi.com, 06.02.2010).

As well known, companies tend to concentrate on future logistics operations. The reason for it is that they see it as an activity field that will earn them the highest value. Thanks to the meliorations made in reverse logistics systems, the profitability of companies increase and their consumer images are effected positively. As a result this operation may be an irrevocable source of profit for the new consumer oriented marketing understanding brought by new economy. (www.onlinekalite.com, 10.08.2009).
For example re-usage of used paper decreases the air pollution by $74-94 \%$, water pollution by $35 \%$ and water usage by $45 \%$ and by adding 1 ton of waste paper to paper pulp, cutting of 8 trees are prevented. (http://www.cevreonline.com, 10.06.2011). Similarly savings can be achieved from crude oil by recycling of plastics. In our country 150-200 thousand tons of plastic is recycled while waste paper recycling ratio is 32\%. (Gürer; Akbulut and Kürklü, 2004).

In Turkey, the number and sectorial distribution of licensed recycling facilities are 5 for batteries, 1 for aluminium, 16 for packaging, 2 for glass, 5 for electronic waste, 3 for rubber, 10 for plastics, 2 for textiles and 5 for oils. (totally 49) (www.geridonusum.org, 04.07.2011).

The success of companies in reverse logistics depends on their conformation with environmental laws, development of customer relations, efforts for increasing profitability, developing policies including cost, decreasing inventory investments and application of a successful efficiency program (Daugherty; Autry and Ellinger, 2001:107-123).

\subsection{The Importance of Timing and Product Structure in Reverse Logistics}

In reverse logistics, the structure of the product that is subject to operation and time factor is very important. The product type effects the profitability of the reverse logistics for the company while the remaining value (obtained after return) of the product and time sensitivity should be taken into consideration for the system product returns must be effective and useful (Nakıboğlu, 2007:181-196).

When the products subject to reverse logistics are checked in means of life cycles, it can be seen that the products having short life cycles should

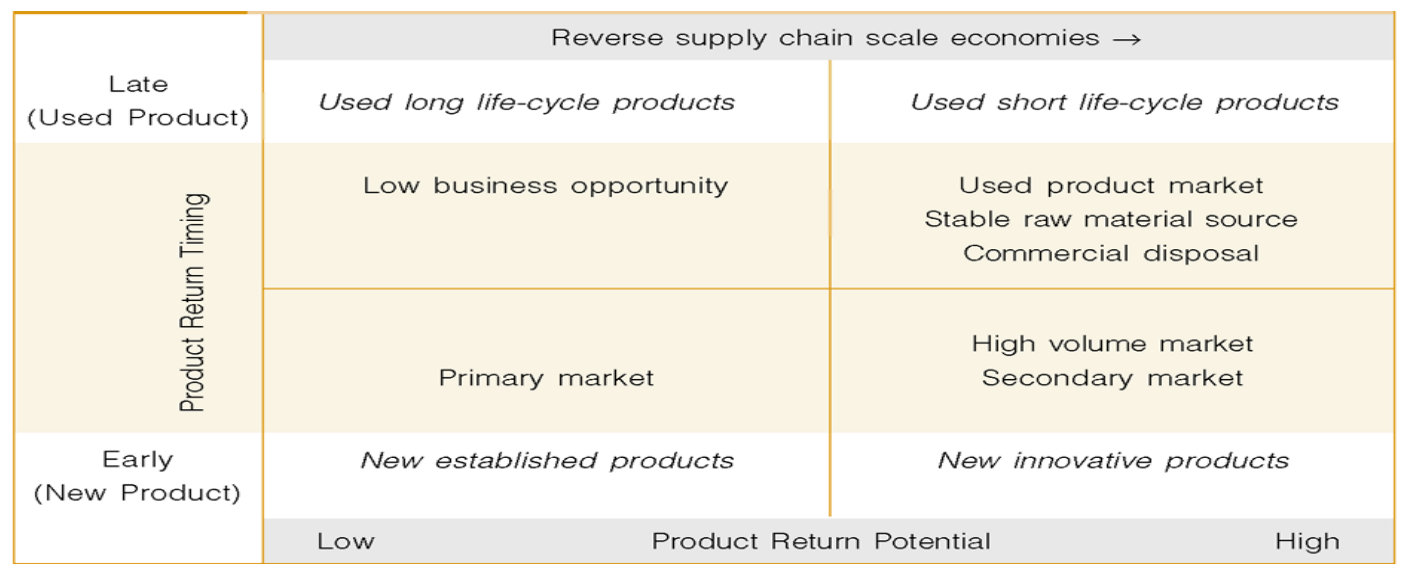

Figure 1: Business Opportunities from Product Returns

(Source: Avittathur, B. ve Shah, J.( 2004) "Tapping Product Returns through Efficient Reverse Supply Chains: Opportunities and Issues", IIMB Management Review, 16(4):84-93) 
be returned faster. For example, the marketing life for PC's are 26 weeks while this period is 9 months for semi conductors. The products having short life cycles lose their values faster the latencies in forward or reverse logistics will cause loss in product value (Stock, 2001: 44-48). According to figure 1 , it is possible to consider the opportunities regarding product returns in reverse logistics in 3 dimensions which are product type and life, product return timing and product return potential. It is also possible to evaluate the reverse logistics opportunities in 4 cells in light of these dimensions. According to the figure, the potential processing opportunities in reverse logistics can be explained as follows (Avittathur ve Shah, 2004:84-93):

- Processing opportunities in returning of products existing in the market: The product that already exists in the market is used before and the users know the product so purchasing has no risk. The returns for these products are due to production error and other quality problems and returning potential of the product right after it is purchased, is low.

- Processing opportunities in returning of products that are new in the market: New products carry some risks for the consumer. Many cell phones and DVD players are in this classification. The return potential of these products are higher than the existing products in the market. The return reasons are mostly due to failing to fulfil customer needs rather than product error. The company may try selling the product in high volume market or sell the product in secondary products market.

- Processing opportunities for used products having a short life time: Products with short life cycle are products in which design changes and developments are made frequently. As new and better versions of the product come out, the consumer wants to renew his product continuously. Although such products like TV, fridge and cars can be used for many years, the consumer may return them for purchasing a newer one.

- Processing opportunities for used products having a long life time: The products with long life cycle are stable and few changes are seen in design. The return potentials of these products are low.

\subsection{Reverse Logistics Process}

The reasons persuading the companies for recycling may be economic factors, legal obligations, environmental anxieties and social responsibility (Brito et all., 2002).
Products, components, equipments and materials may be subject to reverse logistics due to production returns, distribution returns, customer returns, commercial and warranty (Brito; Dekker and Flapper: 2002).

Reverse logistics may be expressed with the below steps (Karaçay, 2005:317-331).

Acceptance: Taking of the product to be recycled from internal or external customer. The order entry or accounting systems of the company is used at this stage (Karaçay, 2005:317-331).

Reuptake: It can be defined as collecting and taking back the product from customers. There are many different types which are:

- Reuptake of stock level returns: Returns from a store or warehouse.

- Reuptake of customer returns: These returns include product recalling, warranty returns and harmed products.

- Return back from collection center: These include product call back, warranty return, inventory return, real return, unused container return, harmed products, seasonal products and hazardous products (Krumwiede and Sheu, 2002:325-333).

$>$ Inspection: Company decides what to do with the returned product. Physical inspection is made and own reproduced product stock is checked too.

Renew: Returned product is fixed / processed. The company may choose to reproduce the product, fix it or reuse it.

$>$ Transfer: Product is transferred through the supply chain of the organization.

$>$ Re-engineering: Management controls the supply chain for the return process to be better (Karaçay, 2005:317-331).

Figure 2 shows the reuptake options as a pyramid. The top of the pyramid shows the global levels such as product and model while lower part shows the more specific levels such as material and energy. The returns at a certain stage of the supply chain can be reuptaken according to the options mentioned in the upper or lower parts of the pyramid (Dekker; Fleischmann; Inderfurth and Wassenhove, 2004:16).

As a result, if none of the reuptake processes can be applied, the product will probably be buries under the soil. On the other hand, burying the products is also a cost item. Besides it harms the environment and so it should be taken into consideration as a social cost item (Bulut and Deran, 2008:325-344). 


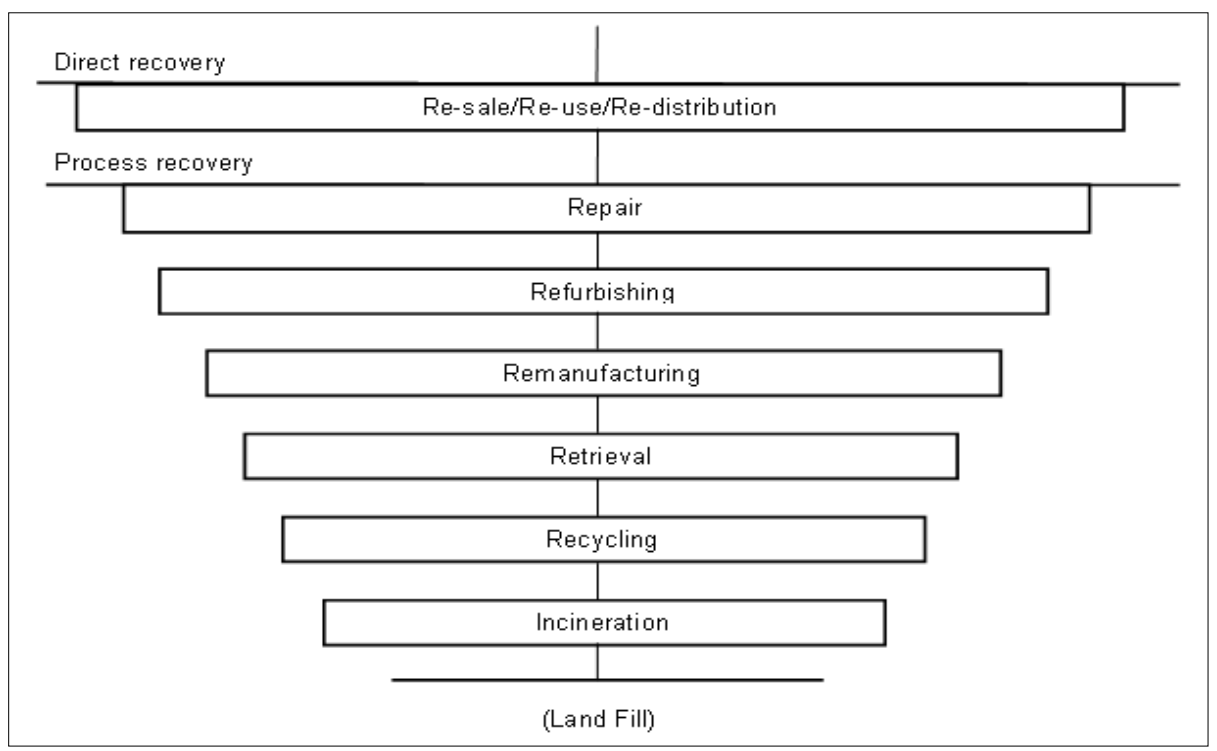

Figure 2: Recovery Option İnverted Pyramid

(Source: Dekker, R., Fleischmann, M., Inderfurth, K. and Wassenhove, L.N.V. (2004), "Reverse Logistics: Quantitative Models for Closed-Loop Supply Chains" Germany, Springer, pp:16)

The channels for returned product are selling in outlet, selling in secondary market, donation to organizations, selling by auction on the internet, etc... (Rengel and Seydl, 2002:1-14).

\subsection{The Handicaps for Reverse Logistics Applications}

These are information and technology system deficiencies, problems regarding the product quality, company policies, resistance against reverse logistics change, lack of suitable performance measures, lack of education, financial limitations, lack of support from upper management, lack of consciousness related with reverse logistics, lack of strategic plan, lack of support from retailers, distributors and dealers (Ravi and Shankar, 2005).

The most serious problem faced by companies in reverse logistics applications is lack of proper information systems (Rogers and Tibben-Lembke, 1998). Perfect information and technology assures the design of the product suitable to environment, recycle, reuse, etc... Therefore pricing in reverse logistics is more difficult than forward logistics.

The company managers which don't take reverse logistics into consideration is related with the policies developed by the company. Together with the renewal and maintenance technologies, sufficient education should be given to the staff in order to adapt them to new technologies (Ravi and Shankar, 2005).

\section{METHODOLOGY AND FINDINGS OF THE RESEARCH}

\subsection{Purpose and Method of The Research}

In this research, the reverse logistics application situations and reasons of the companies in Thrace region was examined. Besides, the return reasons of the products subject to reverse logistics were examined in detail.

The universe of the research consists of companies which function in Thrace region cities (Edirne, Tekirdağ and Kırklareli) Thrace region is one of Turkey's most developed and important regions. Survey was used for collecting data for the research. 110 companies were reached by one to one interviews.

\subsection{Results}

According to the answers given by the 110 companies that are subject to the research, $47.7 \%$ of the companies are in agriculture - food - oil sector, $34.6 \%$ are in textile - shoe sector, $14 \%$ are in paper packaging, iron - steel, glass, shopping, retailing, construction, machinery, metal and various manufacturing sectors while $3.7 \%$ are in chemical pharmaceutical sector. Three companies stated that they do not use reverse logistics applications so they were not taken into consideration. The reasons why companies apply reverse logistics are mentioned in table 1. 
Table 1: The Reasons of Companies to Apply Reverse Logistics Activities

\begin{tabular}{|l|c|c|}
\hline & Frequency & \% Frequency \\
\hline Increasing Customer Satisfaction & 10 & 9,3 \\
\hline Obligation to Apply It & 12 & 11,2 \\
\hline Supporting Other Solution and Services & 14 & 13,1 \\
\hline Increasing Customer Satisfaction + Obligation to Apply It & 15 & 14,0 \\
\hline Increasing Profit + Obligation to Apply & 9 & 8,4 \\
\hline Other & 47 & 44 \\
\hline TOTAL & 107 & 100,0 \\
\hline
\end{tabular}

In table $1,14 \%$ of the companies mentioned about Increasing customer satisfaction + obligation to apply it, $13.1 \%$ mentioned about Supporting other solution and services $11.2 \%$ mentioned about the obligation to apply it, $9.3 \%$ mentioned about increasing customer satisfaction and $44 \%$ mentioned all the above mentioned reasons for performing reverse logistics activities. The reverse logistics types applied by companies are given in table 2 .

Table 2: The Reverse Logistics Applications of Companies

\begin{tabular}{|l|c|c|}
\hline & Frequency & \% Frequency \\
\hline Reproduction / Renewal & 2 & 1,8 \\
\hline Selling to Intermediary Company & 5 & 10,9 \\
\hline Recycle & 4 & 4,5 \\
\hline Disposal & 6 & 3,6 \\
\hline Give the Packages to Licensed Company & 4 & 3,5 \\
\hline Selling to Intermediary Company in Outlet Center & 3 & 2,7 \\
\hline $\begin{array}{l}\text { Arranging the Returning Products From Customers, } \\
\text { Reproduction / Renewal and Recycling }\end{array}$ & 3 & 2,7 \\
\hline $\begin{array}{l}\text { Reproduction / Recycling + Giving The Packages to } \\
\text { Licensed Company }\end{array}$ & 3 & 2,7 \\
\hline $\begin{array}{l}\text { Disposal and Giving the Packages to Licensed } \\
\text { Company }\end{array}$ & 3 & 2,7 \\
\hline $\begin{array}{l}\text { Arranging the Returning Products From Customers, } \\
\text { Storage and Disposal }\end{array}$ & 4 & 1,8 \\
\hline $\begin{array}{l}\text { Storage, Reproduction / Renewal, Selling to } \\
\text { Intermediary Company and Recycling }\end{array}$ & 2 & 3,6 \\
\hline $\begin{array}{l}\text { Reproduction / Renewal, Selling to Intermediary } \\
\text { Company and Giving The Packages to Licensed } \\
\text { Company }\end{array}$ & 4,6 \\
\hline $\begin{array}{l}\text { Reproduction / Renewal, Disposal and Giving the } \\
\text { Packages to Licensed Company }\end{array}$ & 32 & 100,0 \\
\hline $\begin{array}{l}\text { Other } \\
\text { TOTAL }\end{array}$ & 3 & 3 \\
\hline
\end{tabular}

According to the table $2,10.9 \%$ of the companies are selling to intermediary company. They sell their excess products and packages to intermediary companies so they support other solutions and services in production and so they make profit too. $5.5 \%$ are giving the products to companies for reprocessing, $4.5 \%$ are applying recycling (using old product parts) during reproduction. 3.6\% perform reproduction / renewal, selling to intermediary company and giving the packages to licensed company operations and again $3.6 \%$ perform reproduction / renewal, disposal and giving the packages to licensed company operations. $50.3 \%$ of the companies perform a combination of the above mentioned above. These activities are less then 1\% for each activity so they are not placed in the table 2 separately. 
Table 3: The Events Preventing Successful Reverse Logistics Activities of Companies

\begin{tabular}{|l|c|c|}
\hline & Frequency & \% Frequency \\
\hline Company Policies & 1 & 0,9 \\
\hline Financial Sources & 16 & 15 \\
\hline Lack of Information of Management & 2 & 1,9 \\
\hline Insufficiency of Staff Sources & 6 & 5,6 \\
\hline Legal and Environmental Problems & 50 & 46,7 \\
\hline Deficiencies in the System & 10 & 9,3 \\
\hline There is no Prevention & 22 & 20,6 \\
\hline TOTAL & 107 & 100 \\
\hline
\end{tabular}

According to research results $20.6 \%$ of the reverse logistics applying companies state that there is no prevention for reverse logistics activities, $46.7 \%$ state that legal and environmental problems are preventing the success while $15 \%$ state that financial sources prevent the success. $9.3 \%$ of the companies state that lack off system is the reason preventing success while $5.6 \%$ state that staff sources are insufficient for success. $1.9 \%$ state that lack of information in management is the reason preventing the success while $0.9 \%$ of the companies blame the company policies for the reason of prevention.

Table 4: The Processes That are Important for Reproduction Activity Success of Companies

\begin{tabular}{|l|c|c|}
\hline & Frequency & \% Frequency \\
\hline Cleaning & 20 & 18,7 \\
\hline $\begin{array}{l}\text { Supplying the New or Used Parts That Will be } \\
\text { Used in Replacement }\end{array}$ & 9 & 8,4 \\
\hline Classification & 6 & 5,6 \\
\hline Performing The Security / Quality Tests & 36 & 33,6 \\
\hline Reproduction Not Applied & 36 & 33,6 \\
\hline TOTAL & 107 & 100 \\
\hline
\end{tabular}

$33.6 \%$ of the companies which apply reverse logistics didn't answer the question as they do not have reproduction activity. $33.6 \%$ of the companies think that quality and security tests during reproduction are essential. According to $18.7 \%$ cleaning is more important, according to $8.4 \%$, supplying the new or used parts to be used in part replacement is more important while $5.6 \%$ thinks that the importance of classification is bigger.

Table 5: The Return Reasons of the Products

\begin{tabular}{|l|c|c|}
\hline & Frequency & \% Frequency \\
\hline Production Errors & 22 & 20,6 \\
\hline Commercial Return (b2b, b2c) & 18 & 16,8 \\
\hline Product Reclaim & 1 & 0,9 \\
\hline Expiration Of Economic Life & 25 & 23,4 \\
\hline Collecting from Market for Recycling & 19 & 17,7 \\
\hline Excess Production & 22 & 20,6 \\
\hline TOTAL & 107 & 100,0 \\
\hline
\end{tabular}

In table 5, the return reasons of the products to the production facility of the company applying reverse logistics is shown. $23.4 \%$ of the products return due to expired economic life, $20.6 \%$ return due to production errors. $17.7 \%$ are collected from the market for recycling while $16.8 \%$ return due to logistic problems. $0.9 \%$ return as producer detects and error in production and reclaims the product.

\subsection{The Relation Between Capital Structure and Reverse Logistics Application of Companies That are Active in Thrace Region}

In this analysis Chi-square independence test was applied to determine whether the capital structure of companies in Thrace region is independent from reverse logistics activities or not. 
Table 6: The Analysis of the Relation Between Capital Structure and Reverse Logistics Application of Companies

\begin{tabular}{|c|c|c|c|c|c|c|}
\hline & Applying & $\begin{array}{l}\text { Partially } \\
\text { Applying }\end{array}$ & Total & SD & $X^{2}$ & $\mathrm{P}$ \\
\hline Local & 32 & 66 & 98 & \multirow{5}{*}{3} & \multirow{5}{*}{3,635} & \multirow{5}{*}{0,304} \\
\hline Mostly Foreign Capital & 1 & 6 & 7 & & & \\
\hline Foreign & 0 & 1 & 1 & & & \\
\hline Half Local Half Foreign Capital & 1 & 0 & 1 & & & \\
\hline TOTAL & 34 & 73 & 107 & & & \\
\hline
\end{tabular}

As test result in table 6 is $P=0,515>0.05 \mathrm{H} 0$ will be rejected. Therefore it is understood that the capital structures of companies are independent from reverse logistics applications.

\subsection{The Relation Between Activity Periods and Reverse Logistics Application Periods of Companies That are Active in Thrace Region}

The contingence table of the relation between Activity Periods and Reverse Logistics Application
Periods of companies that are active in Thrace Region is given below.

As test result is $\mathrm{P}<0,05 \mathrm{HO}$ will be rejected. Therefore it is understood that the activity periods of companies are not independent from reverse logistics applications. This shows that the environmental responsibility of the companies gains importance in time and also that companies apply reverse logistics activities today due to legal obligation.

Table 7: The Analysis of The Relation Between Activity Periods and Reverse Logistics Application Periods of Companies

\begin{tabular}{|c|c|c|c|c|c|c|c|c|}
\hline & & & e Logis & Application & riods & & & \\
\hline \multirow{5}{*}{ 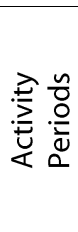 } & & $\begin{array}{c}1-5 \\
\text { Years }\end{array}$ & $\begin{array}{l}\text { 6-10 } \\
\text { Years }\end{array}$ & $\begin{array}{l}11 \text { Years } \\
\text { and More }\end{array}$ & Total & SD & $X^{2}$ & $P$ \\
\hline & 15 Years or Less & 13 & 14 & 17 & 44 & \multirow{4}{*}{4} & \multirow{4}{*}{21,837} & \multirow{4}{*}{0,000} \\
\hline & 16-20 Years & 1 & 3 & 13 & 17 & & & \\
\hline & 21 Years and More & 3 & 5 & 38 & 46 & & & \\
\hline & Total & 17 & 22 & 68 & 107 & & & \\
\hline
\end{tabular}

\section{CONCLUSION}

In Turkey, in effective planning and application of reverse logistics under the scope of its harmony to environment, the aim is to perform the recycling, reusing, re-distribution and disposal activities with respect to environment and with minimum cost. The rapid developments of environmental consciousness, the increasing importance of environmental protective purposes in local and international areas, persuade companies to studies related with reverse logistics.

While test result states that the capital structure of Turkish companies are independent from reverse logistics applications while it also states that the activity periods of these companies are not independent from reverse logistics applications.

Besides these companies are trying to minimize the harm they give to the environment by selling the product and packaging wastes to intermediate companies in stead of disposing them. Therefore they support the source saving that will be used for production of other products.
It should be remembered that the most important factor preventing companies to apply reverse logistics activities successfully is the lack of system. An absence in the system effects the other activities in the organization. The lack of information regarding the necessity of reverse logistics should be removed.

Collection of recyclable products should be a social obligation by the community rather than a commercial activity and the consciousness level of the community should be increased. Besides the collected recycle materials in the companies can be reprocessed in local or international markets. It should be remembered that recycled material has no difference than the other ones; they should have the same warranty periods as the new products and consumers should be convinced that they are suitable for usage. This finding, as in the developed countries indicates that the structural wastes in Turkey should also be converted to a profitable source and allow source optimization to be made. In order to implement their reverse logistics activities, companies have to make new regulations in their own systems, processes and stages of decisions. 
The scope of application of this study is limited to the companies which operate in Trakya region due to time and financial constraints. These companies were chosen by the method of convenience sampling. Even though the scope of the research includes limited business, if it is reflected to whole parts of Turkey, it is thought that the applications of the companies will be similar to the findings of research.
The subject of research, "reverse logistics" concept is an issue of increasing importance with each passing day. As reverse logistics is a new research field in Turkey, there isn't much research on this issue. This research is recommended to be implemented on the companies either in different regions or throughout the country. This research is considered to be a useful resource for those who want to research about reverse logistics and at the same time for correcting the deficiencies in sectors. 


\section{REFERENCES}

Avittathur, B. ve Shah, J. ( 2004) “Tapping Product Returns through Efficient Reverse Supply Chains: Oppourttunities and Issues" IIMB Management Review, 16(4):84-93.

Brito, M. P., Dekker, R. and Flapper, S. D. P. (2002) "Reverse Logistics: A Review of Case Studies" Econometric Institute Report.

Bulut, E. ve Deran, A. (2008) "Reverse Logistics and Its Effects of Cost Management of Companies" Economical Approach, 19:325-344.

Büyüközkan, G. ve Vardaloğlu, Z. (2008) "Green Supply Chain Management” Lojistik Magazine, 8:66-73.

Çancı, M. ve Erdal, M. (2009) Lojistik Yönetimi 3.Baskı, İstanbul, Utikad Yayınları.

Çevreonline, http://www.cevreonline.com/atik2/ geri_donusum.htm, (10.06.2011).

Daughert, P.J., Autry, C. W. ve Ellinger, A.E. (2001) "Reverse Logistics, The Relationship Between Resource Commitment and Program Performance" Journal of Business Logistics, 22(1):107-123.

Dekker, R., Fleischmann, M., Inderfurth, K. and Wassenhove, L.N.V. (2004) Reverse Logistics: Quantitative Models for Closed-Loop Supply Chains, Germany, Springer.

Dyckhoff, H., Lackes, R. and Reese, J. (2004) Supply Chain Management and Reverse Logistic, Germany, Springer.

Erdal, M., Görçün, Ö.F., Görçün, Ö. and Saygilı, M.S. (2008) Integrated Logistics Management, 1.Bask1, İstanbul, Beta Basım Yayım Dağıtım A.Ş.

Gürer, C., Akbulut, H. ve Kürklü, G. (2004) “ Recycling in Conctruction Industry and Re-Usage of Various Construction Materials as A Raw Material Source" 5th Industrial Raw Material Symposium, May 13-14, Izmir.

Karaçay, G. (2005) "Reverse Logistics, Concept and Operation" Çukurova University Social Sciences Institute Magazine, 14(1):317-331.

Krumwiede, D.W. ve Sheu, C. (2002) "A Model for Reverse Logistics Entry by Third-Party Providers" OMEGA The International Journal of Management Science, 30(5):325-333.

Nakıboğlu, G. (2007) "Reverse Logistics: Imortance and Applications in the World" Gazi University, School of Economics and Administrative Sciences, 9(2):181-196.

Online Kalite, www.onlinekalite.com/htmdosyalar/ tersinelojistik.htm, (10.08.2010).
Perşembe Rotasi, http://www.persemberotasi. com/?bolum=yazar\&konu_id=109, (06.02.2010).

Ravi, V. ve Shankar, R. (2005) "Analysis of Interactions Among The Barriers of Reverse Logistics" Technological Forecasting \& Social Change, 72(8):10111029.

Rengel, P. and Seydl, C. (2002) "Completing The Supply Chain Model" School of Business, Stockholm University, Course Paper.

Rogers, D.S. and Tibben-Lembke, R. S. (1998) "Going Backwards: Reverse Logistics Trends and Practices" Reverse Logistics Executive Council.

Stock J. R. (2001) "The 7 Deadly Sins of Reverse Logistics" Material Handling Management, 56(3):5-11.

Şen, E. (2006) "The Importance of Supply Chain Management for Increasing the International Competition Power of SME's." T.C.Prime Ministry Under secretariat of Foreign Trade Export Development Promotion Center, http://www.dkib.org.tr/ UserFiles/ pratik_tedarik.pdf, (20.02.2010).

Şengül, Ü. (2009) "Reverse Logistics Concept and Reverse Logistics Network Design” Atatürk University, 10. Econometry and Statistics Symposium, May 27-29, Erzurum.

Türkiye için Geri Dönüşüm, http://www. geridonusum.org/geri-donusum-rehberi.html, (04.07.2011).

Yüksel, H. (2002) "The Importance of Information Systems in Supply Chain Management" Dokuz Eylül University Social Sciences Institute Magazine, 4(3):261279.

http://www.hilalyildirirkeser.com/hilal/ meslekiuygulama/230730534.pdf, (30.06.2011).

http://www.muhasebedergisi.com/maliyetmuhasebesi/lojistik-maliyetler.html, (29.06.2011). 